\title{
0 cômico e o trágico no conto "O telegrama de Ataxerxes", de Aníbal Machado
}

\author{
José Mário Jovanelli (UEMS)* \\ https://orcid.org/0000-0001-6645-4820 \\ Altamir Botoso (UEMS)** \\ https://orcid.org/0000-0003-3231-2351
}

\section{Resumo:}

Este artigo visa analisar o conto “0 telegrama de Ataxerxes”, de Aníbal Machado, sob a perspectiva do percurso do personagem em sua tentativa de alcançar o objeto de valor, que transformará sua existência. A inaptidão para redigir o telegrama, que permitirá o acesso ao amigo de infância, então Chefe da Nação, é um dos obstáculos que enfrenta. A partir de um advento nomeado por Walter Benjamin de "iluminação profana", o protagonista estabelece conjunção com seu sonho e percorre um caminho marcado pelo acaso, em um jogo entre essência e aparência, realidade e fantasia. Movido pela ilusão, aproxima-se da figura caricata de um alazon moderno. No plano da enunciação, o ironista compõe no conto a alazonia em diferentes situações e modelos de ironia. A sua impotência diante dos fatos faz a diegese desaguar num anticlímax de tragédia. Herói no modelo irônico, sua figura desperta compaixão no leitor, espectador de uma situação que dissolve, no plano da realidade, os sonhos de Ataxerxes e potencializa seu drama na narrativa. Como suporte teórico para as análises, valer-nos-emos dos textos de Aristóteles (2008), Braith (2008), Candido (2002), Muecke (1995), Nadeau (2008), Rosenfeld (2006), Teixeira (2011), dentre outros.

Palavras-chave: "O telegrama de Ataxerxes"; Aníbal Machado; Literatura brasileira; Cômico; Trágico.

\section{Abstract:}

\section{The comic and the tragic in the short story " 0 telegrama de Ataxerxes", by Aníbal Machado}

This article aims to analyze the short story "O telegrama de Ataxerxes", by Aníbal Machado, from character's journey the perspective in his attempt to

\footnotetext{
Mestrando em Letras - Universidade Estadual de Mato Grosso do Sul - UEMS - Campus de Campo Grande-MS - Lattes: http://lattes.cnpq.br/5961206703761645

* Doutor em Letras - Professor do Curso de Letras/Espanhol e do Mestrado em Letras da Universidade Estadual de Mato Grosso do Sul - UEMS - lattes: http://lattes.cnpq.br/4996564101422445
} 
reach the valuable object that will transform his existence. The inability to write the telegram that will allow access to his childhood friend, then Head of the Nation, is one of the obstacles he faces. From an advent named "profane enlightenment" by Walter Benjamin, the protagonist establishes conjunction with his dream and follows a path marked by chance, in a game between essence and appearance, reality and fantasy. Moved by illusion, he approaches the caricatured figure of a modern alazon. At the enunciation level, the ironist composes in the tale the sorrow in different situations and models of irony. His impotence in face of facts makes the diegesis flow into a tragedy anticlimax. A hero in the ironic model, his figure awakens compassion in the reader, a spectator of a situation that dissolves, in reality, Ataxerxes' dreams and enhances his drama in the narrative. As theoretical support for the analysis, we will use the texts by Aristotle (2008), Braith (2008), Candido (2002), Muecke (1995), Nadeau (2008), Rosenfeld (2006), Teixeira (2011), among others.

Keywords: "O telegrama de Ataxerxes"; Aníbal Machado; Brazilian literature; Comic; Tragic.

\section{Introdução}

O conto "O telegrama de Ataxerxes", de Aníbal Machado, foi publicado no livro de contos Vila Feliz ${ }^{1}$. É a história de três personagens que deixam a zona rural em meados do século XX e seguem para a cidade do Rio de Janeiro, capital da República na época. Esses personagens se chamam João Ataxerxes, sua mulher, Esmeralda, e a filha, Juanita.

A família deixa o sítio em razão de uma súbita "revelação" em uma noite em que Ataxerxes se lembra de ter convivido na infância com o então Presidente da República, com quem dividira brincadeiras e de quem

1 Vila Feliz (Rio de Janeiro, José Olympio, 1944) foi o primeiro livro de contos de Aníbal Machado, com as narrativas: "O telegrama de Ataxerxes", "Acontecimento em Vila Feliz", "O piano", "Tati, a garota" e "A morte da porta-estandarte". Na 2. ${ }^{\mathrm{a}}$ edição, em 1959, com o título de Histórias reunidas são inseridas as narrativas: "O Iniciado do vento", "Viagem aos seios de Dúlia", "O defunto Inaugural", "O ascensorista", "O desfile dos chapéus", "Monólogo de Tuquinha Batista" e "O homem alto". Em 1965, o livro recebe o título de $A$ Morte da Porta-Estandarte, Tati, a Garota e Outras Histórias, acrescido do conto "O rato, o guarda-civil e o transatlântico". se tornara amigo. Convencido de que o Zito - apelido do Presidente - o ajudará a alcançar uma posição ilustre, nomeando-o para algum cargo importante no governo, determina a mudança da família para a Capital. Os três deixam o sítio Pedra Branca e partem para a cidade, com sentimentos diferentes em relação àquela aventura. A infausta experiência adquire tom de tragédia, quando a busca pelo reconhecimento da antiga amizade entre Ataxerxes e o Presidente se torna uma obsessão, provocando a desintegração da família, com a morte da mãe e do pai de Juanita.

Marcada pela alternância entre sumários e cenas, a narrativa se estrutura entre o contar e o mostrar, por meio de um narrador em terceira pessoa, heterodiegético - aquele que se posta fora da diegese, com uma focalização, portanto, construída de fora para dentro. No início do conto há uma sincronia espaço-tempo entre fábula e trama, uma vez que a ação motivadora do desejo do protagonista em alcançar o objeto de valor é o 
que justifica os acontecimentos posteriores.

No gênero conto os personagens tendem a ser retratados em suas características básicas, com densidade psicológica elementar, a fim de cumprir seu percurso na narrativa. No texto em estudo, a diegese se realiza a partir das ações do protagonista e a sua ordem estrutura as relações de causas e consequências.

Um dos elementos fundamentais para suporte da fábula no conto é a mudança espacial abrupta do campo para a cidade. Inseridos no ambiente da "civilização moderna", os seres estão à mercê de fatores externos à sua vontade. D. Esmeralda não encontra forças para convencer o marido a voltar para o sítio, e sela melancolicamente seu fim; Juanita, fascinada diante da cidade, vive entre a admiração e o medo do novo e acaba sozinha, morando com desconhecidos. Só Ataxerxes parece acreditar que ali é o seu lugar, bastava ser recebido no gabinete do Presidente para que as coisas se resolvessem.

Os impulsos de Ataxerxes se validam pela força do inconsciente que o domina. 0 motivo inicial de sua busca nasce de uma lembrança repentina, um insight surgido na fronteira entre a realidade e o sonho: "- Acabo de descobrir que o Chefe da Nação foi meu colega! Colega de colégio. Estamos feitos na vida. Era Zito o apelido dele. Meu Deus, como é que só agora pude me lembrar! Deixa eu te abraçar..." (MACHADO, 1997, p. 132).

Essa descoberta, fruto do acaso, o surpreende, pois nela irá acreditar e iniciará sua incessante busca. 0 fato desse acontecimento se passar à noite faz supor que o sonho permitiu uma revelação, na qual o inconsciente se abre à outra realidade, penetrando-a e ocupando o espaço racional: "Altas horas de uma noite nublada de dezembro. Ataxerxes lembrou-se de uma coisa e começou a caminhar agitado pelo quarto" (MACHADO, 1997, p. 132).

Considerando o efeito dessa revelação, é possível compará-la ao que Walter Benjamim, citado por Olgária Matos em "Iluminação Mística, Iluminação Profana: Walter Benjamin" (1994) chama de

'iluminação profana' - aquela que o Sujeito clássico não pode, com sua lógica linear, alcançar. Entre os fenômenos apreendidos por uma "iluminação profana", Benjamin coloca o acaso, noção que o pensamento racionalista confunde com ilusão, pois, a exemplo da consciência empírica, a consciência reflexiva coloca seus objetos na "realidade". Acaso pois: encontro ou desencontro. (BENJAMIN apud MATOS, 1994, p. 88).

Embora não se constitua exatamente em uma iluminação profana por não se contrapor ao sagrado, base do conceito de Walter Benjamin, a iluminação de Ataxerxes provoca a abertura para uma realidade abstrata em que o espaço, o tempo e os valores sociais colocam o personagem à margem de uma existência factual, no mesmo instante que origina sua busca. A trama, iniciada por essa revelação, justifica as atitudes do protagonista e o impulsiona em direção ao seu destino, percorrendo um caminho em que a sorte e o azar se alternam em um percurso marcado pelo acaso. 0 herói se torna vítima de seu próprio desejo, o que fatalmente, culminará na sua tragédia.

A seguir, apontamos alguns elementos do Surrealismo que podem ser verificados no conto e procedemos à sua análise, com ênfase na comicidade e no trágico que permeiam o trajeto do personagem central da narrativa.

\section{Traços surrealistas}

O Surrealismo, uma das vanguardas artísticas do século XX, nasceu na França, no início do século XX e se estendeu pelos países 
europeus, influenciando artistas também da Ásia, África e América. Segundo Maurice Naudeau (2008), em História do surrealismo, essa estética considera que "o real é coisa diferente daquilo que vemos, ouvimos, tocamos, sentimos, degustamos. Existem forças desconhecidas que nos regem, mas sobre as quais podemos esperar agir. Resta ir empós de sua descoberta" (NADEAU, 2008, p. 18).

No Brasil, autores como Jorge de Lima (1893-1953), Murilo Mendes (1901-1975), Rosário Fusco (1910-1977) e Aníbal Machado (1894-1964), todos modernistas, receberam influência, ou se vincularam de alguma forma ao surrealismo. Principalmente em Aníbal Machado, o surrealismo despertou interesse maior como é possível notar em sua obra. Ele era leitor e divulgador do movimento e, além de ter como referência autores ligados ao surrealismo, uma de suas práticas era anotar seus sonhos e os colocar em textos literários, procedimento comum aos surrealistas. Nesse sentido, o próprio Aníbal Machado, em 1951, em uma entrevista ao jornalista Jones Rocha, declara:

Pelo poder do sonho e da imaginação atravessamos a fronteira do cotidiano e incorporamos um domínio donde a vida profunda não cessa de acenar-nos. A importância do surrealismo, como doutrina e como ação, se caracteriza por essa procura sistemática de um mundo maravilhoso, que parece zombar de nossa mediocridade, mediante os seus contínuos e constantes afloramentos no campo da vida prática. (MACHADO, 1951, p. 60).

O crítico M. Cavalcanti Proença, sobre a narrativa de Aníbal Machado, salienta que ela "se desenvolve em terreno fronteiriço, ora pisando chão de realidade, ora pairando nas nuvens do imaginário, entre sonho e vigília, entre espírito e matéria, verdade e mentira, relatório e ficção" (PROENÇA, 1997, p. xvi).
Sigmund Freud, em seus estudos sobre o sonho, considera que "o sonho é a realização de um desejo" e acrescenta que uma das características da memória no sonho é que ela

Têm à sua disposição as impressões mais primitivas da nossa infância e até fazem surgir detalhes desse período de nossa vida que, mais uma vez, parecem-nos triviais e que, em nosso estado de vigília, acreditamos terem caído no esquecimento há muito tempo. (FREUD, 2010, p. 104).

No conto, a origem da trajetória de Ataxerxes, nascida a partir de um sonho ou de uma súbita revelação, está ligada à sua memória da infância. Assim, o personagem está conectado ao universo da estética surrealista, a qual se estende por toda a narrativa, ora caminhando pela cidade e se encantando por ela como um flâneur, ora como um personagem guiado por uma ilusão, obstinado na sua busca pelo encontro com o amigo. Ataxerxes vive uma realidade interior, que se choca com o mundo fora dele, ligando o irreal com o real. Para ele, acreditar em imagens da infância, distorcidas ou não pelo tempo, verdadeiras ou falsas não importa, o fato é que elas o subordinarão a uma nova existência, e seu mundo será visto e sentido de acordo com as forças invisíveis que o governam.

Ataxerxes cria sua própria realidade e a vontade de estabelecer contato com seu amigo domina sua imaginação. Esses impulsos repentinos do inconsciente já o haviam dominado em outras circunstâncias. Por meio de analepses, situações anteriores análogas às que ele vive são reveladas. Dona Esmeralda, em uma tentativa de demover o marido de seu intento, argumenta:

- É uma aventura, Xerxes. Não fique zangado com o que vou dizer, mas você sempre foi assim, meu marido. Vive contando com 
o acaso. No começo, foi com os diamantes; por causa de um que encontrou por acaso, o nosso quintal ficou lá todo revolvido; depois, você se meteu com o zebu, lembra-se? e foi aquele desastre; depois com o cristal; agora é com o Presidente. Que é da resposta ao telegrama, Xerxes?!... (MACHADO, 1997, p. 134).

O conjunto dos eventos que ligam presente e passado da vida de Ataxerxes nos permite entender sua personalidade, reforçando a verossimilhança da narrativa, que desvela uma série de fracassos do personagem, no que tange aos projetos nos quais ele se empenhou.

O mundo descontínuo provocado pelo acaso é uma das características da construção da linguagem literária de Aníbal Machado. No conto, o protagonista se revela um sujeito em constantes preparativos. 0 pesquisador da obra de Aníbal Machado, Marcos Vinícius Teixeira, afirma que, para o autor, o sujeito

nunca atingirá uma meta, pois não a tem, vive sempre provisoriamente, se coloca de antemão como perdedor na disputa inevitável, prefere passar despercebido, permite-se enxergar a vida e o mundo como algo inacabado. Atingir a meta, chegar ao topo, consagrar-se está na contramão de viver, de buscar o modo de viver, de se preparar constantemente para qualquer coisa quenão importa se acontecerá, pois o mais importante é estar em preparativos (TEIXEIRA, 2011, p. 12).

Podemos observar no conto que o mundo agitado em que Ataxerxes se meteu representa essa descontinuidade de ações. Não há uma fixação no objetivo, que é a redação do telegrama, seja por inaptidão, seja por desvios provocados pelo emaranhado dos acontecimentos ao seu redor: pessoas que se reúnem para ouvi-lo; a folha que se perde levada pelo vento e que se cola nas ro- das de um caminhão; a cidade e sua vida agitada; os homens de negócio que o procuram. Esses fatos provocam uma descontinuidade, a ponto de Ataxerxes duvidar se enviou, ou não, o telegrama a seu amigo presidente, ou seja, o personagem está sempre em preparativos para um futuro que nunca acontece.

\section{0 cômico}

Motivado pelo seu desejo, o protagonista é inserido em um ambiente urbano, já com ares de modernidade que se contrapõe ao sítio onde vivia. Fascinado pela civilização e obstinado na busca pelo seu espaço nessa sociedade, dedica-se a escrever o texto que enviará ao seu amigo. Nesse ponto, a narrativa revela uma de suas oposições fundamentais: o desejo de redigir o telegrama e a incapacidade de fazê-lo. A busca pelas palavras "certas" ou "adequadas" à situação se transforma em uma luta sem fim, que tensiona toda a narrativa, motivada pela sua inaptidão em juntar as palavras que produzam o efeito de impressionar o destinatário. Suas atitudes e seu esforço são narrados em tom irônico, devido não só à sua inaptidão em escrever, como também pela incongruência entre a estrutura discursiva pretendida e a objetividade própria do telegrama, gênero textual marcado pela comunicação abreviada por uma linguagem elíptica, direta. Assim, motivado pelo desejo e ao sabor do acaso, suas ações revelam um Ataxerxes sonhador, ingênuo e confuso e, por meio dele, observamos o caráter cômico do texto, que se configura no conto por intermédio da ironia.

A forma mais comum de se conceber a ironia é como a figura de linguagem, em que se diz o contrário do que realmente se quer dizer, potencializando sutilmente a crítica ou o escárnio, o que configura a ironia retórica. Mas o significado do termo ironia vai além do jogo entre o dito e o não dito. 
Em Aristóteles (2008), aparece em algumas versões da Poética no sentido de peripeteia - peripécia - como inversão da ordem natural das ações. Na República de Platão (2017), aparece como eironeia - uma estratégia de enganar o outro, elogiando-o. Aristóteles via a eironeia como o disfarce das verdadeiras intenções, por meio da desvalorização do próprio sujeito. 0 oposto à eironeia é a alazoneia, que consiste na dissimulação por meio da autovalorização, ostentando os feitos de maneira arrogante. A partir dessas definições, cria-se a figura do eiron, aquele que se esconde, disfarçando-se como um ser inferior, e do alazon, aquele que se realiza pela bajulação e pelo aplauso. As duas denominações propostas por Aristóteles carregam suas mentiras estabelecidas no jogo da realidade e aparência.

Até o Romantismo, o sentido de ironia pouco se estendeu além de "dizer uma coisa para significar outra", a partir daí adquire uma forma discursiva que revela a subjetividade do ironista - o "eu" emissor - como uma das formas de repúdio ao objetivismo clássico. Para isso, houve a necessidade de se conquistar o leitor e contar com a capacidade deste para obtenção dos resultados pretendidos, já que o texto aprofunda o caráter subjetivo e irônico. 0 receptor se torna, portanto, peça fundamental para a construção do sentido pretendido pelo enunciador. A partir do século XX, a tentativa de representação do mundo moderno pela arte, principalmente pela linguagem verbal, fez com que o viés irônico do texto literário se relacionasse com um enunciado/enunciação, de modo a provocar uma abertura a um campo de significações que intensifica a dependência dos leitores e de sua bagagem cultural na captura dos sentidos. Por isso, a ironia assumirá graus diferentes em cada situação.
D. C. Muecke (1995), em Ironia e o Irônico, considera que a ironia será mais ou menos poderosa de acordo com o tópico ou tema abordado, porque alguns já estão incorporados no leitor, havendo um envolvimento natural com determinadas situações. Portanto, o jogo entre razão e emoção (ou loucura), entre realidade e desejo, onde o personagem está envolvido, desperta de imediato graus de ironia, compaixão, aversão, crítica de juízo moral etc. Muecke (1995, p. 76) ainda acrescenta que "as áreas de interesse que mais prontamente geram ironia são, pela mesma razão, as áreas em que se investe mais capital emocional: religião, amor, moralidade, política e história". Esses "tópicos" já conhecidos diminuem a subjetividade com que cada um encara a situação vivida pelo protagonista, já que o leitor se depara com situações que podem, ou não, compor seu universo e estarem circunscritas em sua realidade.

Ironia e humor são formas de sátira, enquanto a ironia busca um sentido subjacente ao fato ou à circunstância narrada, o humor se liga à incongruência de uma situação a partir de um pensamento particular. $\mathrm{Ou}$ seja, a ironia está contida nas entrelinhas, propondo significações sem contestar as normas sociais, já o humor é marcado pela subversão do sentido por meio de significantes diretos. A ironia, portanto, se estrutura na organização do discurso, explora mais a mente do que os sentidos, com uma enunciação em que a sagacidade e a sutileza do ironista se mostram e se escondem, de acordo com suas intenções e o discernimento do seu leitor, por isso é sempre aberta e depende do sistema de valores construídos dentro da própria narrativa.

O significado de ironia, na sua concepção clássica, também está ligado à filosofia. Aristóteles (2008) a considera como pro- 
cedimento imanente ao ser humano, e seu uso determina uma atitude pessoal. Em textos recuperados de Platão, Sócrates desenvolve a ironia por meio da dialética, ou arte de dialogar. No romantismo, ela passou a ser associada à idealização e à finitude do mundo sem desconsiderar, no entanto, o seu caráter retórico-filosófico. Com os estudos linguísticos desenvolvidos no século $\mathrm{XX}$, a ironia passou a ser concebida, sem desconsiderar seu caráter linguístico ou filosófico, como um traço da linguagem que encontra no processo de enunciação o elemento básico para sua elaboração. Em seus estudos sobre a ironia, Beth Brait (2008), em Ironia em perspectiva polifônica, constata que sob uma perspectiva discursiva, a ironia está presente por meio de "marcas da enunciação irônica, detectadas a partir de um discurso literário" (BRAIT, 2008, p. 40-41), e acrescenta que

tanto de uma perspectiva linguística, que concebe a ironia como uma construção de linguagem, quanto de uma perspectiva filosófica, que a vê como uma atitude, como marca de personalidade, como postura estético-filosófica, o elemento que está no centro dos dois caminhos é o processo de enunciação.

No conto, o discurso revela traços de ironia a partir do comportamento de Ataxerxes, como um ato de linguagem não direto de sutil ironia. As marcas enunciativas de ironia estão no próprio desenrolar da trama onde Ataxerxes é o centro de situações engraçadas.

$\mathrm{Na}$ classificação de ironia estabelecida por D. C. Muecke (1995) destacam-se a ironia instrumental e a ironia observável. Para o referido estudioso, na primeira o ironista diz alguma coisa para vê-la rejeitada como falsa, unilateral, entre outros; na segunda, o ironista apresenta algo irônico - uma situa- ção, uma sequência de eventos, uma personagem, uma crença, entre outros - que existe, ou pensa que existe, independentemente da apresentação. Nesse caso, o fato em si não se justificaria por uma ação espontânea do personagem, com ou sem intenção de logro, mas aconteceria simplesmente por causa do destino. Obviamente que, por trás da enunciação, há um enunciador construindo uma narrativa, que permite a intervenção de forças não humanas. No conto, são as ações conscientes, ou não, do personagem, que dão sustentação à ironia, aproximando-o da figura do alazon. Segundo Muecke (1995, p. 55-56),

[...] somente na Ironia Observável, segundo parece, é que temos a alazonia ou o alazon, definindo-se a alazonia como a inconsciência confiante encontrada no ou imputada ao alazon, a vítima da ironia [...] tais pessoas tendem a enganar a si mesmas mais do que àquelas a quem se vangloriam e chegam a acreditar em suas próprias invenções. [...] $\mathrm{o}$ alazon pode ser totalmente irreflexivo, ou atrevidamente confiante; ou pode ser infinitamente circunspecto, vendo toda cilada menos aquela em que ele cai.

Podemos considerar nessa classe de alazons, por exemplo, personagens como Dom Quixote e Policarpo Quaresma, no sentido de representarem aqueles comportamentos "irresponsáveis", cujas consequências os ridicularizam e expõem a fragilidade de seus ideais diante de um universo que se contrapõe a eles. Uma distinção em relação ao alazon descrito por Muecke (1995) é que esses personagens não visam tirar proveito de situações para benefício próprio. De forma análoga, Ataxerxes se caracteriza como alazon, na medida em que é bajulado por ser considerado "alguém importante", mas sua imagem é construída por um discurso que não visa enganar os ouvintes com mentiras. O mundo de fantasia, fruto de seu sonho, 
não permite usar da lógica racional no plano da realidade concreta, então se deixa levar pelo acaso ingenuamente. Ataxerxes acredita em seu discurso, que se torna verdadeiro para ele e para os que o cercam, excluindo notadamente sua mulher Esmeralda.

Elementos como o espaço, o tempo, o contexto histórico, enfim, a ambientação se tornam fundamentais para a existência do alazon. No caso de Ataxerxes, o Rio de Janeiro da década de 1940, a Segunda Guerra Mundial, o Capitalismo, os homens de negócios, as diversões noturnas o envolvem em uma atmosfera de modernidade, que delineia suas atitudes e o aproxima de um personagem moderno. Sobre a arte e o personagem modernos, Anatol Rosenfeld tece a seguinte observação:

[...] sem dúvida se exprime na arte moderna uma nova visão do homem e da realidade ou, melhor, a tentativa de redefinir a situação do homem e do indivíduo, tentativa que se revela no próprio esforço de assimilar, na estrutura da obra-de-arte (e não apenas na temática), a precariedade da posição do indivíduo no mundo moderno. (ROSENFELD, 2006, p. 97).

Assim, o personagem moderno é visto sob a perspectiva de um ser fragmentado, que muitas vezes transita à margem de uma sociedade ideal à procura de sua identidade e de seu espaço. A complexidade desse personagem se estende a um narrador também diferente do tradicional que, geralmente, procurava se distanciar do mundo narrado, projetando seu personagem num espaço e tempo lógicos, impondo uma ordem narrativa que, aparentemente, nada tinha a ver com a visão de mundo do autor (ou do narrador). Era a condição privilegiada do narrador realista. A perspectiva do narrador moderno não permite total onisciência e distanciamento do seu mundo narrado. Nes- se sentido, a ironia ressurge como estratégia de composição narrativa, mas subordina sua capacidade de absorção às habilidades do ironista e do leitor no entrelaçamento de sentidos que podem ser captados parcial ou totalmente.

Na história, explícita ou sutil, a ironia está focada principalmente nos procedimentos do protagonista, o alazon, por meio da ironia observável. Mas não só com Ataxerxes podem-se observar situações irônicas que prenunciam um final infeliz. Na descrição da chegada da família à capital notamos antíteses, que marcam essa desventura:

A cidade sorri pelas miríades de janelas de seu casario aceso [...] o trem vai perdendo as energias e se deixando morrer na plataforma. Logo depois, pela janela do vagão saem sacos, cestos e velhas malas da fazenda. Em seguida, pela porta de trás, os Ataxerxes. (MACHADO, 1997, p. 134).

As marcas enunciativas se contrapõem, por exemplo, em "sorri" e "perdendo as energias e se deixando morrer" e "pela porta de trás". Também o nome da pensão onde se hospedam - Estrela do Norte - não condiz com o local onde funciona: "Ali é apenas um trecho lívido e deserto de quarteirão, escondendo o crime, escondendo o amor, [...]" (MACHADO, 1997, p. 134).

Cômico, e menos trágico, é o fato de o aspecto físico do Chefe da Nação no retrato pendurado na parede da pensão não estabelecer relação direta com o companheiro de infância que Ataxerxes descreve: "Hoje está calvo, mas possuía bela cabeleira.”, “... sei que agora estão completamente azuis [os olhos]; naturalmente com a idade e o exercício do poder tudo isto vai mudando..." (MACHADO, 1997, p. 137-138).

Um recurso narrativo constante no conto é a alternância entre o discurso indireto e o indireto livre, que potencializa o efeito 
de comicidade, como por exemplo, a dificuldade de Ataxerxes em escrever o telegrama:

Pela primeira vez Ataxerxes experimenta a sensação física das palavras. Pena não ser como esses escritores famosos que lidam com elas e sabem manipular todos os sentimentos. Agora, - por exemplo, precisava suscitar no Presidente uma impressão de volta à infância; em seguida, de poder pessoal - o que seria fácil; depois, de piedade pelos fracassados da vida; aí então, já na fase final, o coração do Presidente estaria preparado a receber a semente do pedido. (MACHADO, 1997, p. 139-140).

Nesse trecho, a ironia se constrói tanto pelo caráter metalinguístico, ao se refere à imagem do escritor - que o senso comum considera um sujeito enganador que usa de seu talento para manipular palavras bonitas de acordo com a situação - e tirar algum proveito; quanto pela associação das etapas de construção do texto, tal como as de cultivo da terra para plantio.

Há trechos em que a ironia se presta a uma crítica social pelo jogo de aparências e segunda intenções. As pessoas que se aproximam de Ataxerxes pela sua suposta amizade com o Presidente o tratam com amabilidade:

Com o tempo, cresceu a roda de Ataxerxes. De toda parte apareciam-lhe amigos. Caras novas. Figuras vorazes, rápidas, de olhos ardentes. Alguns o levavam aos cassinos onde travava conhecimento com homens prósperos e ativos, pessoas amáveis propondo negócios que não entendia bem, devido ao barulho do jazz e ao esplendor das girls. Pagavam-lhe a ceia, conduziam-no de carro até a porta da pensão. Eram cavalheiros obsequiosos, corretamente vestidos, todos muito apressados. Alguns tinham ciúmes dos outros. (MACHADO, 1997, p. 142).

Os traços irônicos do discurso estão na qualificação das pessoas como "amigos", "amáveis", "obsequiosos" e soam como iro- nia retórica para os leitores porque escondem as verdadeiras intensões delas. 0 alazon, sujeito irreflexível, não consegue perceber os reais objetivos dos outros, nem sua precária condição diante dos fatos.

\section{0 trágico}

Aristóteles (2008), na Poética, considera que o âmago da tragédia está na abrupta mudança da trajetória dos personagens. A alteração de percursos, mais ou menos estáveis, geram os traumas que fazem o personagem perceber que ele não é o que projeta, gerando uma crise de identidade. No conto, pode-se considerar que a alteração no curso da vida de Ataxerxes se dá pelo acaso: sonho de infância ou revelação súbita, a trama se liga à trajetória da "segunda etapa" de sua vida, na qual a tragédia já atua no jogo entre realidade e ilusão. No entanto, Ataxerxes não tem consciência de sua condição de vítima diante das circunstâncias, e a tragédia se mostra mais dolorosa a cada ação sua. Seus atos acabam envolvendo-o em uma teia de situações, que o encaminham para o desastre, já que não há a percepção de que o desvio do rumo em sua vida não lhe traz resultados favoráveis.

Desse modo, o personagem vai se embrenhando em uma atmosfera que aos poucos desfaz seus sonhos no mesmo sentido em que aumentam suas atitudes ridículas, reforçando o caráter abnegado demonstrado desde o início. Nesse sentido, o personagem pode ser caracterizado como plano ou de costume, e segundo Antonio Candido (2002), é o que desencadeia o processo de construção da caricatura:

As "personagens de costumes" são, portanto, apresentadas por meio de traços distintivos, fortemente escolhidos e marcados; por meio, em suma, de tudo aquilo que os distingue vistos de fora. Estes traços são fixa- 
dos de uma vez para sempre, e cada vez que a personagem surge na ação, basta invocar um deles. Como se vê, é o processo fundamental da caricatura, e de fato ele teve o seu apogeu, e tem ainda a sua eficácia máxima, na caracterização de personagens cômicos, pitorescos, invariavelmente sentimentais ou acentuadamente trágicos. Personagens, em suma, dominados com exclusividade por uma característica invariável e desde logo revelada. (CANDIDO, 2002, p. 58).

Cômico, pitoresco e sentimental, Ataxerxes se revela, no percurso narrativo, um ser cada vez mais fragilizado. Apesar de, às vezes, ser chamado à realidade, a ingenuidade parece aumentar e o imerge gradativamente em um mundo ilusório. Sua figura é ridicularizada, sua esperança se desvanece na mesma medida em que tenta outras estratégias para contatar seu amigo, mas suas atitudes e comportamentos só fazem aumentar a distância entre ele e Zito. O leitor se aproxima de Ataxerxes em um sentimento de compaixão, um dos traços do gênero tragédia.

Além disso, o discurso indireto livre vai compondo com ironia sutil uma atmosfera concentrada, criando uma tensão que aguça a curiosidade do leitor:

O Catete se conservava silencioso. Com certeza, lá se estava conjecturando o que seria reservado a Ataxerxes. Daí a demora. O Zito não falharia.

Ataxerxes via-o passar às vezes em grande velocidade, precedido de batedores de motocicleta. Vinham-lhe neste momento ímpetos de atirar-se à frente e gritar: - Sou eu, Zito, o teu amigo Ataxerxes. Quase na miséria, como vês...

Mas a imponência e a rapidez do espetáculo deixavam-no perturbado.

Contentava-se, então, em bater palmas de longe. Às vezes, o único a fazê-lo... (MACHAD0, 1997, p. 146-147).
Começou a frequentar os vestíbulos do Palácio do Catete, em uma espera interminável pelo encontro pessoal com o amigo. Os contínuos e os soldados já estavam habituados com a sua presença, até que um dia Ataxerxes perde a cabeça e xinga. Foi colocado para fora: "Posto na rua, exclama: - Vocês vão ver depois! É porque ele não ouviu a minha voz!... Um dia hão de saber quem sou eu! Afinal, isso aqui é ou não é uma democracia?... Canalhas! saibam que o Presidente é meu amigo..." (MACHADO, 1997, p. 152).

A palavra "democracia" acentua o tom contraditório de seu desabafo, na medida em que se contrapõe semanticamente às expressões "hão de saber quem sou eu!" e “o Presidente é meu amigo..." reforçando o estado mental confuso e ilógico em que se encontra, cada vez mais frágil e patético. 0 contraste, nesse caso, é condição primordial para a ironia (MUECKE, 1995).

Faz parte também do processo de construção da ironia, o que Muecke nomeia de "princípio do alto-contraste". Este se traduz por indicar o aumento da disparidade entre "o que se pode esperar e o que realmente acontece" (MUECKE, 1995, p. 74). No caso da aventura de Ataxerxes, o resultado cabe mais ou menos nas expectativas do leitor, no sentido de um resultado nada favorável para o herói, e Muecke complementa afirmando que:

Este princípio do alto-contraste se aplica também ao alazon. Em vez de aumentar o fosso entre a aparência e a realidade, ou entre a expectativa e o evento, pode-se exagerar a confiança cega do alazon ou a circunspecção, ingenuidade ou perseverança que ele demonstra em tentar evitar o inevitável. (MUECKE, 1995, p. 74).

0 alto-contraste, então, se manifesta pela gradativa alteração do estado mental de Ataxerxes. Suas ações desesperadas tensionam 
a narrativa e o levam à desesperada tentativa de encontrar o amigo por outros meios. Convicto de que Zito não o recebera ainda porque fora impedido, resolve, por fim, ir até sua residência. Em uma cena quixotesca, Zamboni, um amigo da pensão, apoia Ataxerxes nos ombros, que olha por cima do muro, reconhece o presidente, tenta chamá -lo e recebe um tiro da sentinela:

Esperaram a noite e tocaram para lá. Encostaram-se ao muro. Xerxes trepou nos ombros do italiano.

- Cuidado. Suba por aqui!

- Não! Me levanta um pouco mais... Aquelas árvores me atrapalham. Agora! Estou vendo tudo! Ali deve ser o escritório... Que beleza este parque... Entrou uma menina; deve ser Clotilde, a filha.

- E o homem?

- Espera! espera! Não faça barulho... Psiu! Ai que ele vem entrando!... Meu Deus, estou pertinho dele! Como emagreceu! Sentou-se. Acho que está triste... acendeu um charuto!...

- Você está distinguindo bem? sussurra Zamboni. Eu também estou com vontade de espiar.

- Você não, Zamboni, que pode atrapalhar. Até os seus olhos azuis estou vendo!... Mas como ficou calvo!... De tanto se preocupar com a Pátria, não é, Zamboni?

- Ah, sim... com certeza!

- Acho que vou dar um assobio.

- Não faça isso, você está louco?

- Coitado, agora está descansando... trabalha tanto!... Estou quase ouvindo a respiração dele.

- Cuidado! não fale alto. É melhor descer...

- Não; é só transmissão de pensamento... Zito! Zito!... - chamou de novo num cicio. Tão simples que ele é... Meu amigo!... - Olhou para as alamedas; - Que silêncio no parque! Zito! Zito! Adivinha só quem está aqui!...
Houve um tiro seco. Ataxerxes rolou. Zamboni correu. A noite prosseguiu calma. (MACHADO, 1997, p. 157).

0 final trágico do herói determina o fim da possibilidade de encontro entre os amigos de infância, e o desfecho da história traz Juanita revirando os guardados do pai, onde se encontra o rascunho do telegrama: "Naquele papel sujo, ia decifrando o mistério da vida de seu pai - o drama de Ataxerxes" (MACHADO, 1997, p. 158).

Ainda sobre o termo tragédia e nos remetendo novamente a Aristóteles (2008) e sua Poética, a tragédia se compõe de uma narrativa que desperta no leitor temor e compaixão no processo de catarse. A trajetória do protagonista pode nos levar a compartilhar de sua desventura, justamente por se tratar de um personagem infantilizado por suas ações, retratado de forma irônica e preso ao seu destino. Sua ingenuidade diante do mundo provoca o riso, mas o aproxima do leitor acostumado a alazons dispersos nas narrativas de outras épocas. Aristóteles também considera que são dois os efeitos psicológicos resultantes da desgraça do herói. Um se refere ao fato de acharmos que o infortúnio do outro nos causará desgraça semelhante e está prestes a acontecer, o outro "refere-se que daqueles que são atingidos pela desgraça sem o merecer devemos compartilhar a pena e ter compaixão" (ARISTÓTELES, 2008, p. 15). Parece-nos que o fim de Ataxerxes está ligado a esse sentimento.

Na questão da recepção do texto, além da catarse, um efeito comum nos leitores é a sensação de liberdade pela consciência de se estar lidando com um personagem vítima do acaso, atado ao seu destino e preso em sua própria armadilha. Segundo Muecke (1995), quando observamos do alto da nossa condição de leitores, colocamos a vítima em uma posição hierarquicamente inferior, 
nesse caso o herói toma a classificação de "herói irônico".

Também concebida como um "princípio estruturador do discurso", segundo Beth Brait (2008), a ironia se vale da intertextualidade para potencializar sentidos enunciativos. Nesse sentido, para Ataxerxes, o Chefe da Nação possui status de rei: "Ataxerxes será um dos favoritos de sua corte" (MACHADO, 1997, p. 158), em uma possível alusão ao poema "Vou me embora pra Pasárgada", de Manuel Bandeira, publicado pela primeira vez no livro Libertinagem, em 1930. A utopia do eu lírico no poema consiste em desfrutar das maravilhas de Pasárgada, a cidade do Rei Ciro II, O Grande, construída para ser a capital do império Persa (século VI a.C.). Em situação análoga, o desejo de Ataxerxes equivale ao do sujeito lírico, no sentido de obter regalias e vantagens por ser "amigo do rei". O próprio nome do personagem nos remete a Xerxes, neto do rei Ciro, que se torna imperador e combate os gregos, nas Guerras Médicas, séc. V a.C. (VILAR, 2013). Embora seu exército fosse mais numeroso, Xerxes sofre uma vergonhosa derrota, que o faz cair no ostracismo. Pode-se interpretar que o protagonista do conto de Aníbal Machado seja o representante caricatural de Xerxes, que não atinge seu objetivo mesmo estando muito perto da vitória e Ataxerxes do Palácio do rei (Catete).

$\mathrm{Na}$ composição do personagem, portanto, há elementos heroicos, cômicos e trágicos concebidos a partir de um sujeito à mercê de acaso. A figura caricatural na qual Ataxerxes se torna, deixa-o à margem de sua conquista, assim como a cidade, em sua dinâmica, vai absorvendo e repelindo seus habitantes e moldando-os de acordo com a capacidade de cada um em entendê -la e adaptar-se, criando utopias e desfazendo sonhos.

\section{Conclusão}

A zona de conforto e segurança em que nos colocamos diante da tragédia também nos faz refletir sobre uma realidade do mundo civilizado. A feição crítica do texto está ligada ao abismo social existente entre classes de poder e o cidadão comum, às injustiças e aos meios de se obter vantagens no universo da modernidade em que vive o personagem, e que por extensão atinge a todos.

Após a morte do pai, uma caixa com as coisas de Ataxerxes chegam às mãos da filha, Juanita:

Começou a examinar os papéis: cautelas de casas de penhor, recibos de tintureiro, listas de jogo de bicho, uma fotografia do Presidente, uma carta de Pedra Branca, um retratinho de Esmeralda. Bilhetes corridos de loteria espalharam-se pelo chão. Havia também um charuto inacabado. (MACHADO, 1997, p. 159).

Esses papéis refletem simbolicamente o que teria sido a vida do pai até aquele instante: cautelas de casas de penhor - dívidas; jogo do bicho e bilhetes de loteria - esperança; carta de Pedra Branca e o retrato de Esmeralda - o passado; fotografia do Presidente - o presente e, talvez, o futuro. Entre os guardados há duas folhas "manchadas de gordura e suor" (MACHADO, 1997, p. 158), o que restou do telegrama, simbolizando a vida confusa que tivera seu pai. 0 inventário da vida de Ataxerxes reduz sua existência a uma incessante busca impulsionada pelo acaso e alimentada pelo inconsciente, que deságua em uma dissolução de planos, dilacerados pela realidade da qual o protagonista se afastara há muito tempo.

Não menos trágico se afigura o futuro de Juanita, personagem ligada ao movimento e aos elementos fundamentais: água, ar, fogo e terra. Dançarina, acompanha com movimentos de corpo, desde criança, o balanço 
das folhas de bananeiras no sítio. Na cidade, dança diante do mar, na praia, e do fogo, por ocasião de um incêndio; faz curso de dança e se destaca. Depois da morte da mãe e do pai, a disjunção da personagem com os elementos fundamentais é potencializada: sozinha, triste; as pessoas que a cercam se preocupam com ela, mas em seu íntimo pressente uma "catástrofe irremediável" (MACHADO, 1997, p. 159). Fechada em casa, tem nas fotografias da mãe e do pai as únicas referências de seu passado.

0 conto se fecha com uma espécie de moral que, de certo modo, justifica as atitudes impulsivas e obstinadas de Ataxerxes, que o humaniza e se estende a todos os homens: "Quem nunca teve no bolso ou no pensamento um telegrama com o pedido impossível?..." (MACHADO, 1997, p. 159). Dessa maneira, o cômico e o trágico se misturam no universo da ilusão no qual viveu Ataxerxes, o "homem em preparativos", incapaz de desvincular ilusão e realidade, até ser tragado pela morte.

\section{Referências}

ARISTÓTELES. Poética. Tradução de Ana Maria Valente. 3. ed. Lisboa: Calouste Gulbenkian, 2008.

BRAIT, B. Ironia em perspectiva polifônica. 2. ed. Campinas: Editora Unicamp, 2008.

CANDIDO, A. et al. A personagem de ficção. 10. ed. São Paulo: Perspectiva, 2002.
FREUD, Sigmund. A interpretação dos sonhos. São Paulo: Folha de São Paulo, 2010.

MACHADO, A. A morte da porta-estandarte, Tati, a garota e outras histórias. 15. ed. Rio de Janeiro: José Olympio, 1997.

MATOS, O. Iluminação Mística, Iluminação Profana: Walter Benjamin. Discurso, (23), 87-108, 1994.

MUECKE, D. C. Ironia e o irônico. São Paulo: Perspectiva, 1995.

NADEAU, M. História do Surrealismo. Tradução de Geraldo Gerson de Souza. São Paulo: Perspectiva, 2008.

PLATÃO. A República. Tradução de Maria Helena da Rocha Pereira. 15. ed. Lisboa: Calouste Gulbenkian, 2017.

PROENÇA, M. C. Os balões cativos. In. MACHADO, A. A morte da porta-estandarte, Tati, a garota e outras histórias. 15. ed. Rio de Janeiro: José Olympio, 1997.

ROSENFELD, A. Texto/contexto I. São Paulo: Perspectiva, 2006.

TEIXEIRA, M. V. Aníbal Machado: um escritor em preparativos. Tese (Doutorado em Literatura Brasileira), Departamento de Letras Clássicas e Vernáculas da Faculdade de Filosofia, Letras e Ciências Humanas da Universidade de São Paulo - FFLCH-USP, São Paulo, 2011.

VILAR, L. Xerxes: o Rei dos Reis. 28 abr. 2013. Disponível em: <http://seguindopassoshistoria.blogspot.com/2013/04/xerxes-o-rei-dos -reis.html> Acesso em: 12 jun. 2019.

Recebido em: $10 / 04 / 2021$

Aprovado em: 08/06/2021 